\title{
Correction to: General anaesthesia related mortality in a limited resource settings region: a retrospective study in two teaching hospitals of Butembo
}

\author{
Furaha Nzanzu Blaise Pascal ${ }^{1,2^{*}}$, Agnes Malisawa ${ }^{3}$, Andreas Barratt-Due $^{4}$, Felix Namboya ${ }^{1}$ and Gregor Pollach ${ }^{1}$
}

\section{Correction to: BMC Anesthesiol 21, 60 (2021) https://doi.org/10.1186/s12871-021-01280-2}

Following publication of the original article [1], the authors reported an error in Figs. 1 and 2 wherein the two figures were swapped and two typo errors. One typo is found under the Results section, 2nd sentence of the 3rd paragraph the word "non-emergent" was changed to "non-emergency" and the word "that" found in 1st sentence of the 5th paragraph under Discussion section was deleted.

The correct figures are as follows:

The original article has been corrected.

\section{Author details}

${ }^{1}$ Department of Anaesthesia and Intensive Care, College of Medicine, University of Malawi, Blantyre, Malawi. ${ }^{2}$ Faculty of Medicine, Université Catholique du Graben, Butembo, Democratic Republic of the Congo. ${ }^{3}$ Matanda Hospital of Butembo, Butembo, Democratic Republic of the Congo. ${ }^{4}$ Division of Emergencies and Critical Care, Rikshospitalet, Oslo University Hospital, Oslo, Norway.
Published online: 16 March 2021

\section{Reference}

1. Blaise Pascal FN, Malisawa A, Barratt-Due A, et al. General anaesthesia related mortality in a limited resource settings region: a retrospective study in two teaching hospitals of Butembo. BMC Anesthesiol. 2021;21:60 https:// doi.org/10.1186/s12871-021-01280-2.

* Correspondence: blaisepascal.furaha@gmail.com

'Department of Anaesthesia and Intensive Care, College of Medicine, University of Malawi, Blantyre, Malawi

${ }^{2}$ Faculty of Medicine, Université Catholique du Graben, Butembo, Democratic Republic of the Congo

Full list of author information is available at the end of the article

(c) The Author(s). 2021 Open Access This article is licensed under a Creative Commons Attribution 4.0 International License, which permits use, sharing, adaptation, distribution and reproduction in any medium or format, as long as you give appropriate credit to the original author(s) and the source, provide a link to the Creative Commons licence, and indicate if changes were made. The images or other third party material in this article are included in the article's Creative Commons licence, unless indicated otherwise in a credit line to the material. If material is not included in the article's Creative Commons licence and your intended use is not permitted by statutory regulation or exceeds the permitted use, you will need to obtain permission directly from the copyright holder. To view a copy of this licence, visit http://creativecommons.org/licenses/by/4.0/ The Creative Commons Public Domain Dedication waiver (http://creativecommons.org/publicdomain/zero/1.0/) applies to the data made available in this article, unless otherwise stated in a credit line to the data. 

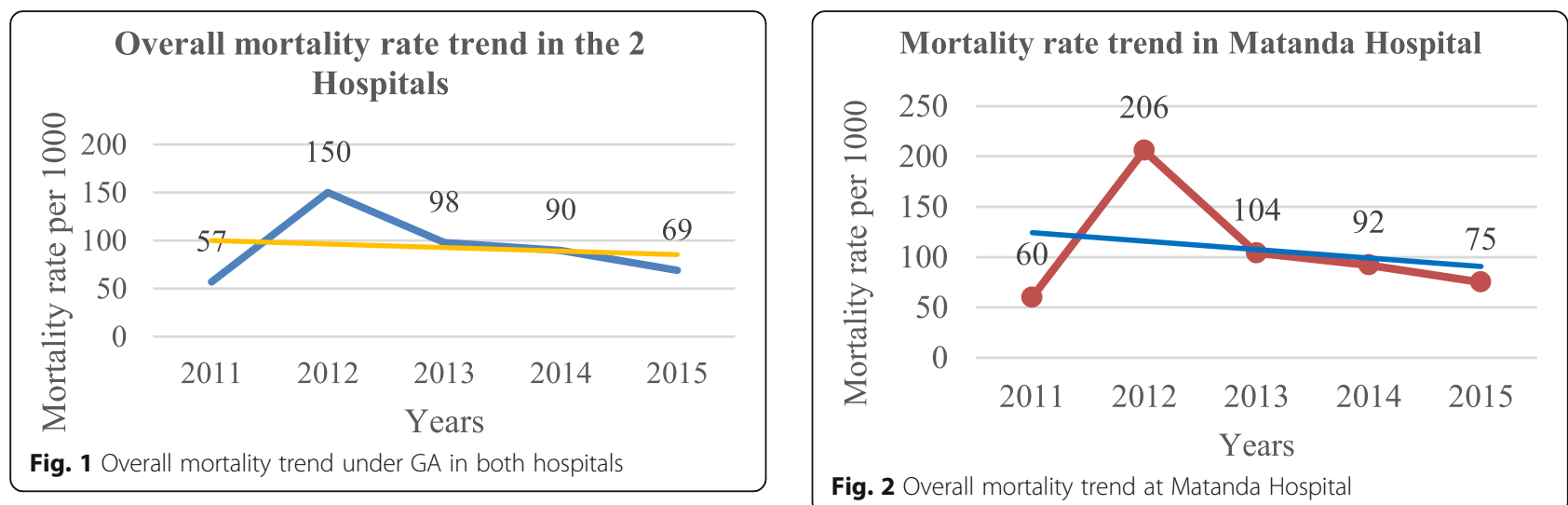

Fig. 2 Overall mortality trend at Matanda Hospital 